Bangladesh J. Bot. 42(2): 215-222, 2013 (December)

\title{
COMBINING ABILITY STUDIES FOR DEVELOPING NEW RICE HYBRIDS IN BANGLADESH
}

\author{
MJ HASAN*, UK KULSUM, LF LiPI AND AKM SHAMSUDDiN ${ }^{1}$
}

Hybrid Rice Division, Bangladesh Rice Research Institute, Gazipur, Bangladesh

Key words: Combining ability, CMS line, hybrid rice and yield.

\begin{abstract}
Combining ability on grain yield and its components from line $\times$ tester analysis of 70 rice hybrids produced by crossing seven CMS lines and ten testers of local and exotic origin were studied. The analysis revealed higher sca variance than gca variance for all the traits indicating the prevalence of non-additive gene action. Testers played important role towards panicle length (48.18\%), spikelet fertility $(60.46 \%)$ and grain yield/plant (55.44\%) indicating predominant of paternal influence for these traits. The contribution of interactions (line $\times$ tester) were found vital for plant height (58.55\%), effective tillers/plant (51.69\%), days to $50 \%$ flowering (48.95\%), days to maturity (48.32\%), flag leaf length $(68.55 \%)$, panicles $/ \mathrm{m}^{2}(48.61 \%)$ and panicle weight (50.39\%). D.ShanA was the only good general combiner among the female parent for earliness and dwarfness. Male parent IR64R was best general combiner for dwarfness. The crosses BRRI9A $\times$ BR168R and D.ShanA $\times$ BR168R were identified as most promising for yield and desired traits based on sca effects, per se performance and gca effects of parents for grain yield and its components in rice which could be exploited beneficially in future rice breeding program by adopting heterosis breeding strategy.
\end{abstract}

\section{Introduction}

Rice is the principal food crop and most extensively grown cereal in the tropical and subtropical regions of the world. Today, rice has special position as a source of providing over $75 \%$ of Asian population and more than three billion of world populations meal which represents 50 to $80 \%$ of their daily calorie intake (Khush 2005, Amirjani 2011). This population will increase to over 4.6 billion by 2050 (Honarnejad et al. 2000) which demands more than $50 \%$ of rice needs to be produced what is produced present to cope with the growing population (Ashikari et al. 2005, Srividya et al. 2010). Bangladesh is the fourth largest producer and consumer of rice in the world with an annual production ranging from 28 to 33 million tons which constitutes $94.38 \%$ of the total food grain (rice and wheat). But it is an unfortunate paradox that yield of rice, the staple food of Southeast Asia, in lowest in area where the crop has been cultured extensively since ancient times and the plant exist in its greatest varietal diversity (Jennings 1964). Development of rice hybrids with yield advantage of 30 per cent over the existing hybrids is the turning point for increasing production and productivity (Yuan 1994). In hybrid program, choice of suitable parents is of primary importance since per se performance of parents is not always a true indicator of its combining ability in hybrid combination (Swamy et al. 2003). Therefore, performance of a $F_{1}$ hybrid depends on choice of parents. Several methods like per se performance, genetic diversity, combining ability etc., have been attempted to select the parents. Among them combining ability analysis offers a powerful tool for estimating the value of a parent to produce superior hybrid. The combining ability studies of the parents provide information which helps in the selection of better parents for effective breeding. Its role is important to decide parents, crosses and appropriate breeding procedure to be followed to select desirable segregants (Salgotra et al. 2009). Keeping this in view, the present investigation was carried out to study the combining ability in order to identify good combiners and superior hybrid combinations.

*Author for correspondence: <jamilbarri@yahoo.com>. 'Department of Genetics and Plant Breeding, BAU, Mymensingh, Bangladesh. 


\section{Materials and Methods}

The experiment was conducted at the experimental farm of Bangladesh Rice Research Institute (BRRI) during T. Aman season of 2009 and Boro season of 2009-10. The pre-germinated seeds of selected seven CMS and ten restorers (pollen parent) lines were sown separately during $\mathrm{T}$. Aman season of 2009, in a staggered way so as to get synchronization in flowering to facilitate easy hybridization in a line (CMS line) $\times$ tester (restorer) fashion to obtain 70 hybrids. Seedlings of each of these lines were raised in bed and 21 days old seedlings were transplanted in single plant/hill in the experimental plots in three different blocks. The plots were 2.5 meter in length containing five rows. The plant spacing provided was $20 \mathrm{~cm}$ between rows and $15 \mathrm{~cm}$ between plants of the same row. In flowering stage spikelets of CMS lines were clipped off and pollinated with restorer lines. There were 7 CMS and 10 restorer lines which gave $70 \mathrm{~F}_{1}$ hybrids in line $\times$ tester combinations. To produce sufficient amount of seeds 8 plants from each CMS lines crossed with each restorer lines. Seventy hybrids along with their corresponding parents and check varieties was grown in Boro season 2009-2010 with three replications. Individual plot size was 2 $\mathrm{m}^{2}$ containing 50 plants in each entry with a spacing of $15 \mathrm{~cm}$ between plants and $20 \mathrm{~cm}$ between rows. Soil fertility was ensured by applying appropriate doses of fertilizer according to seasons and necessary inter culture operations and irrigation were made whenever required. Ten sample plants were randomly selected from each plot excluding the border plants and the following data were recorded: Plant height, days to $50 \%$ flowering, number of panicles $/ \mathrm{m}^{2}$, flag leaf length, panicle length, spikelet/panicle, spikelet fertility, grain yield/plot, 1000 grain weight and days to maturity. Collected data were subjected to statistical analysis using line $\times$ tester analysis by Kempthorne (1957).

\section{Results and Discussion}

Analysis of variance for yield and different yield contributing characters revealed significant variations for all the characters except for panicle weight (Table 1). The crosses also exhibited significant variations among all these characters except for effective tillers/plant and panicle weight. Similar trend of variations were observed for parents. Variance due to interaction effect of parents and crosses were highly significant for all the traits except panicle weight, which was significant at $5 \%$ level of significance. The variances due to restorer lines (tester) were found significant for all the characters except panicle weight. Variation among CMS lines was significant for all the characters studied. The ratio of gca to sca variances ranged from 0.01 to 0.38 . These results indicated that the non-additive gene actions predominated over the additive gene actions for all the characters. Predominance of non additive gene action for grain yield and its components was also reported by many other workers (Satyanarayana et al. (2000), Rita and Motiramani (2005); Singh et al. (2005); Venkatesan et al. (2007) and Dalvi and Patel (2009).

The proportional contribution of lines, testers and their interaction for yield and yield contributing characters are presented in Table 2. It is evident from the table that testers played important role towards panicle length (48.18\%), spikelet fertility $(60.46 \%)$, grain yield/plant (55.44\%) indicating predominant of paternal influence for these traits. On the contrary, maternal lines contributed most (40.61\%) towards 1000 grain weight. The contribution of maternal and paternal interactions (line $\times$ tester) were found vital for plant height $(58.55 \%)$, effective tillers/plant (51.69\%), days to $50 \%$ flowering $(48.95 \%)$, days to maturity $(48.32 \%)$, flag leaf length (68.55\%), panicles $/ \mathrm{m}^{2}$ (48.61\%) and panicle weight (50.39\%). General combining ability (gca) effects are presented in Table 3. 


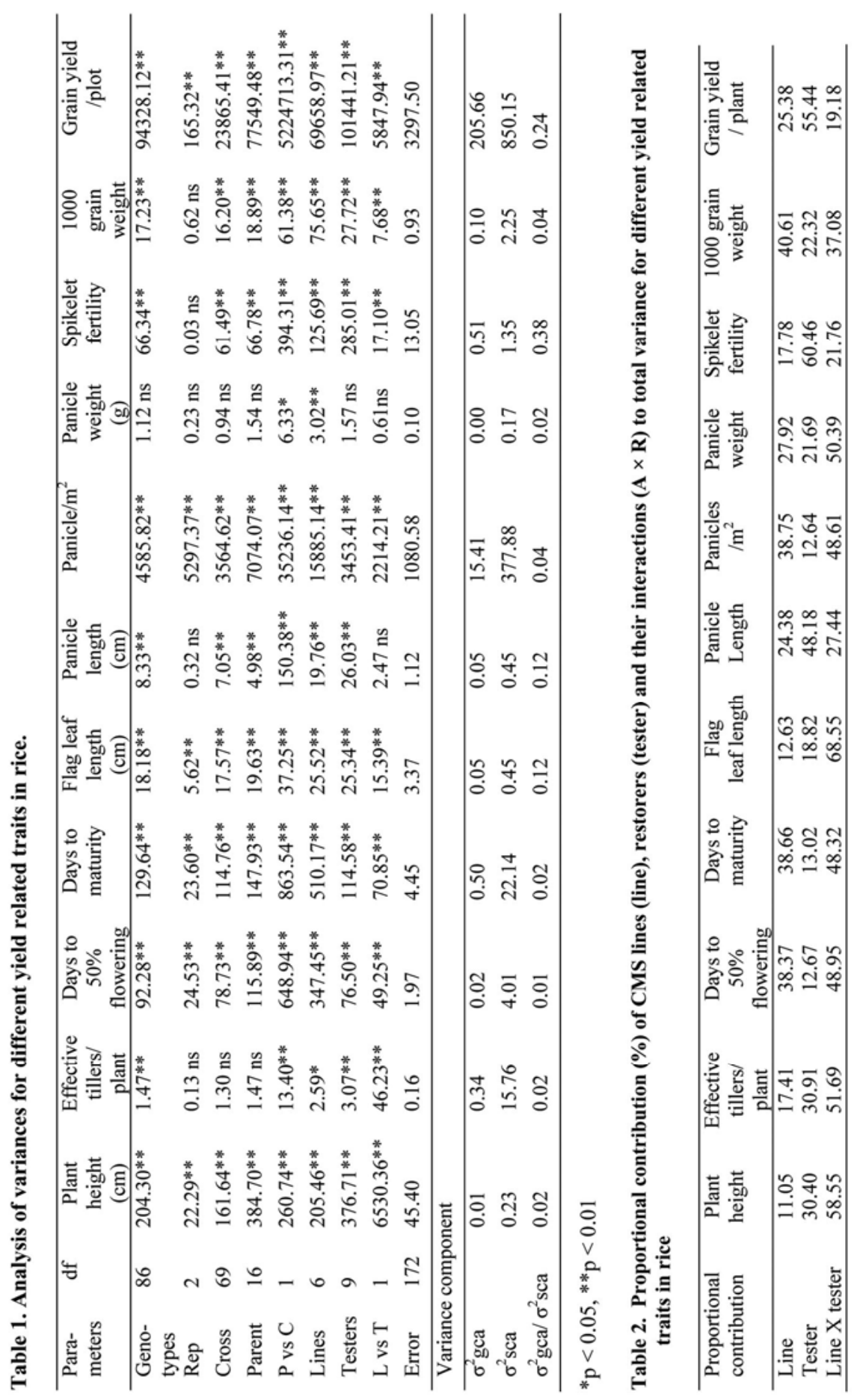




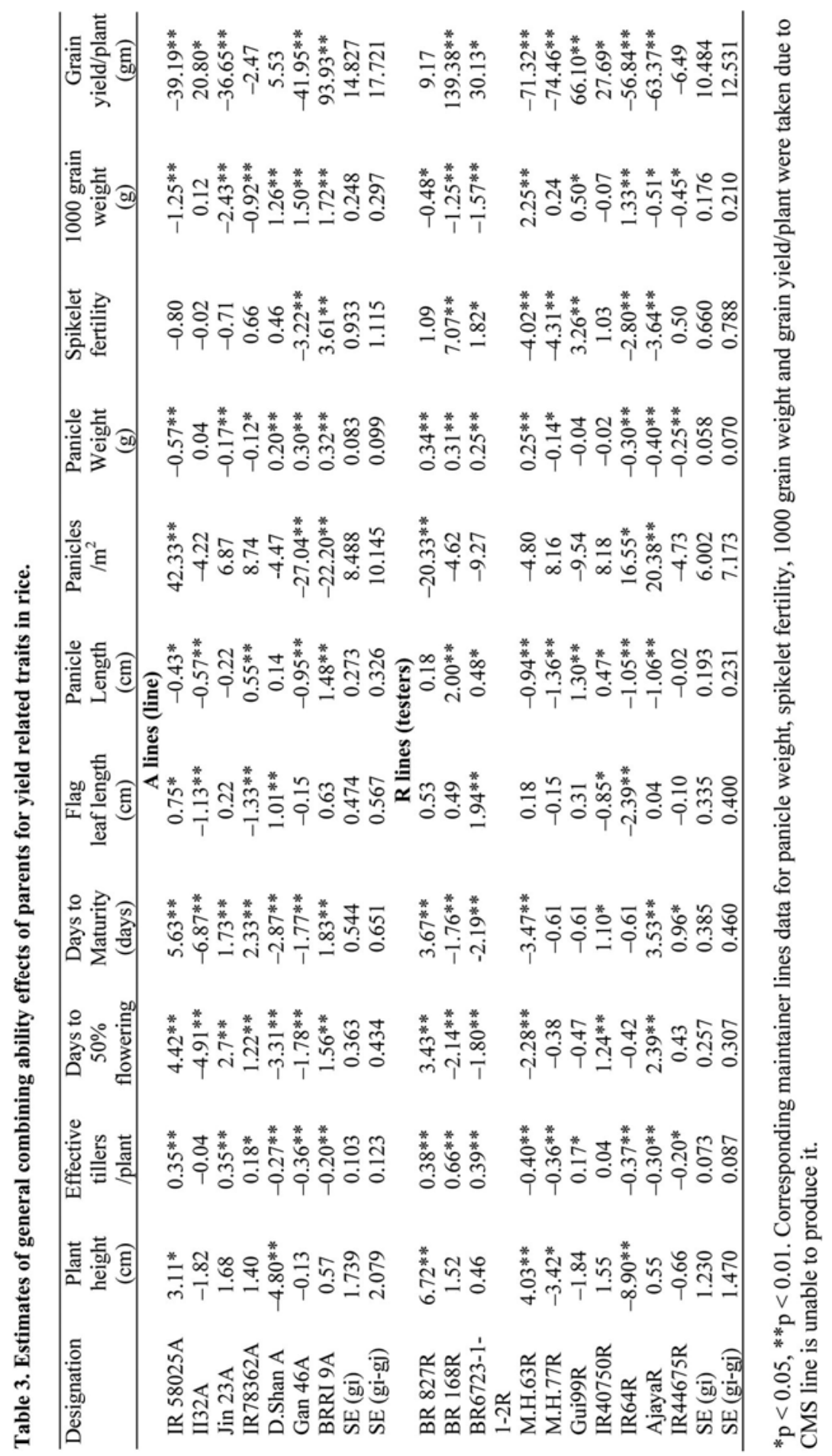


Among the CMS line IR58025A exhibited highly significant positive gca effects while D.ShanA showed significant negative gca effects for plant height. While the testers BR827R and M.H.63R showed highly significant positive gca effects but IR64R and M.H.77R had highly significant negative gca effects for plant height. From the above results, it could be suggested that the parents D.ShanA, IR64R and M.H.77R would be good general combiner for short stature of plant. The CMS line IR58025A and Jin23A considered as the best general combiner followed by BR168R, BR6723-1-1-2R and BR827R which could be utilized for evolving more tillers/plant. Richharia and Singh (1983) and Sarker (2001) reported similar sorts of results in rice.

The CMS line II32A, D.ShanA and Gan46A were good combiners for earliness due to having negative and significant gca effects for days to $50 \%$ flowering. The restorer lines M.H.63R, BR168R and BR6723-1-1-2R exhibited highly significant and negative gca effects indicating good general combiner for earliness but BR827R, AjayaR and IR40750R were regarded as poor general combiner for days to $50 \%$ flowering due to possess significant and positive gca effects. This indicated that II32A, D.ShanA and Gan46A were good general combiners for earliness and could be useful for further breeding program. The testers M.H.63R, BR6723-1-1-2R and BR168R were identified as the best general combiners for earliness due to their significant and negative gca effects. The lines D.ShanA and IR58025A showed significant positive gca effects, while IR78362A and II32A showed significant negative gca effects for flag leaf length. This indicated that D.ShanA and IR58025A contributed positive alleles for flag leaf length and IR78362A and II32A had some undesirable alleles for flag leaf length. Saidaiah et al. (2010) reported both negative and positive gca effects for flag leaf length while working with different CMS lines for developing new hybrids over environments. The restorer line BR6723-1-1-2R exhibited highly significant positive gca effects for flag leaf length.

For panicle length significant positive gca effects were found in BRRI9A and IR78362A, while significant negative gca effects were found in Gan46A, II32A and IR58025A. Positive significant gca effects were exhibited by BR168R, Gui99R, BR6723-1-1-2R and IR40750R which was considered as best general combiners for panicle length. Sharma et al. (2005) reported major role of non-additive gene action in rice for panicle length. The line IR58025A exhibited significant positive gca effects while Gan46A and BRRI9A showed significant negative gca effects for panicles $/ \mathrm{m}^{2}$. The restorer AjayaR and IR64R gave highly significant positive gca effects indicating some favorable alleles for this trait in them. All the CMS lines showed significant gca effects for 1000 grain weight except II32A and it ranged from -0.57 to 0.32 . The restorer lines BR827R, BR168R, BR6723-1-1-2R and M.H.63R showed highly significant positive gca effects indicating presence of positive alleles for panicle weight and which could be fixed in subsequent generations.

For spikelet fertility gca effects ranged from -3.22 to 3.61 in CMS and -4.31 to 7.07 in restorer lines. BRRI9A showed highly significant positive gca effects, while Gan46A exhibited highly significant negative gca effects. BR168R considered as best general combiner followed by Gui99R and BR6723-1-1-2R which could be utilized as parent for breeding genotype with more fertile grains per panicle. Sarker (2001) and Bashar (2002) reported either female or male parent with good general combiner for 1000-grain weight. Significant positive gca effects were found in CMS lines BRRI9A and II32A and considered as the best general combiners for yield/plant. On the other hand, significant positive gca effects was found in BR168R, Gui99R and BR6723-1-12R. The result indicated that BRRI9A, Jin23A, II32A, BR168R, Gui99R, BR6723-1-1-2R and IR40750R were the best general combiners for this trait. Singh and Kumar (2004) observed several hybrids having high gca effects for grain yield in rice. 
Table 4. Top five crosses with high sca effects, per se performance and gca effects of parents for grain yield and its components in rice.

\begin{tabular}{|c|c|c|c|c|c|}
\hline \multirow{2}{*}{$\begin{array}{l}\text { Character/ } \\
\text { crosses }\end{array}$} & \multirow{2}{*}{$\begin{array}{c}\text { Mean } \\
\text { performance }\end{array}$} & \multirow[t]{2}{*}{ sca effect } & \multicolumn{2}{|c|}{ gca effect } & \multirow[t]{2}{*}{ gca status } \\
\hline & & & Female parent & Male parent & \\
\hline \multicolumn{6}{|l|}{ Days to $50 \%$ flowering } \\
\hline Gan46A/Gui99R & 108.33 & $-7.46^{* *}$ & $-1.78^{* *}$ & -0.47 & $\mathrm{~L} \times \mathrm{L}$ \\
\hline II32A/IR44675R & 109.00 & $-4.57 * *$ & $-4.91 * *$ & 0.43 & $\mathrm{H} \times \mathrm{L}$ \\
\hline D.ShanA/IR44675R & 109.33 & $-5.83 * *$ & $-3.31 * *$ & 0.43 & $\mathrm{H} \times \mathrm{L}$ \\
\hline D.ShanA/BR6723-1-1-2R & 110.33 & $-2.60 * *$ & $-3.31^{* *}$ & $-1.80 * *$ & $\mathrm{H} \times \mathrm{H}$ \\
\hline II32A/BR168R & 110.67 & $-0.33^{*}$ & $-4.91 * *$ & $-2.14 * *$ & $\mathrm{H} \times \mathrm{H}$ \\
\hline \multicolumn{6}{|l|}{ Plant height (dwarfness) } \\
\hline BRRI9A/BR168R & 79.90 & $-21.04 * *$ & 0.57 & 1.52 & $\mathrm{~L} \times \mathrm{L}$ \\
\hline IR78362A/IR44675R & 84.07 & $-15.52 * *$ & 1.40 & -0.66 & $\mathrm{~L} \times \mathrm{L}$ \\
\hline D.ShanA/IR64R & 85.03 & -0.12 & $-4.80 * *$ & $-8.90 * *$ & $\mathrm{H} \times \mathrm{H}$ \\
\hline IR58025A/M.H.77R & 85.22 & $-13.32 * *$ & $3.11^{*}$ & $-3.42^{*}$ & $\mathrm{~L} \times \mathrm{H}$ \\
\hline Jin23A/IR64R & 87.00 & $-4.63^{* *}$ & 1.68 & $-8.90^{* *}$ & $\mathrm{~L} \times \mathrm{H}$ \\
\hline \multicolumn{6}{|l|}{ No. of effective tillers/plant } \\
\hline BRRI9A/BR168R & 9.00 & $1.34 * *$ & $-0.20 * *$ & $0.66 * *$ & $\mathrm{~L} \times \mathrm{H}$ \\
\hline IR58025A/IR40750R & 8.60 & $1.01^{* *}$ & $0.35^{* *}$ & 0.04 & $\mathrm{H} \times \mathrm{L}$ \\
\hline IR58025A/ BR6723-1-1-2R & 8.33 & $0.40^{* *}$ & $0.35^{* *}$ & $0.39 * *$ & $\mathrm{H} \times \mathrm{H}$ \\
\hline Jin23A/BR168R & 8.20 & -0.01 & $0.35^{* *}$ & $0.66^{* *}$ & $\mathrm{H} \times \mathrm{H}$ \\
\hline Jin23A/Gui99R & 8.10 & $0.37 * *$ & $0.35 * *$ & $0.17^{*}$ & $\mathrm{H} \times \mathrm{H}$ \\
\hline \multicolumn{6}{|l|}{ Panicle length } \\
\hline BRRI9A/BR168R & 28.86 & $0.50 * *$ & $1.48^{* *}$ & $2.00 * *$ & $\mathrm{H} \times \mathrm{H}$ \\
\hline IR78362A/BR168R & 27.90 & $0.47 * *$ & $0.55^{* *}$ & $2.00 * *$ & $\mathrm{H} \times \mathrm{H}$ \\
\hline BRRI9A/Gui99R & 27.86 & 0.21 & $1.48 * *$ & $1.30 * *$ & $\mathrm{H} \times \mathrm{H}$ \\
\hline BRRI9A/BR6723-1-1-2R & 27.79 & $0.96^{* *}$ & $1.48 * *$ & $0.48^{*}$ & $\mathrm{H} \times \mathrm{H}$ \\
\hline D.ShanA/BR168R & 27.46 & $0.44 * *$ & 0.14 & $2.00 * *$ & $\mathrm{~L} \times \mathrm{H}$ \\
\hline \multicolumn{6}{|l|}{ Panicle weight } \\
\hline D.ShanA/BR168R & 4.92 & $0.91 * *$ & $0.20 * *$ & $0.31^{* *}$ & $\mathrm{H} \times \mathrm{H}$ \\
\hline Gan46A/BR827R & 4.65 & $0.51 * *$ & $0.30 * *$ & $0.34 * *$ & $\mathrm{H} \times \mathrm{H}$ \\
\hline Gan46A/IR40750R & 4.46 & $0.68 * *$ & $0.30 * *$ & -0.02 & $\mathrm{H} \times \mathrm{L}$ \\
\hline II32A/M.H.63R & 4.35 & $0.57 * *$ & 0.04 & $0.25 * *$ & $\mathrm{~L} \times \mathrm{H}$ \\
\hline BRRI9A/BR168R & 4.23 & $0.11 * *$ & $0.32 * *$ & $0.31^{* *}$ & $\mathrm{H} \times \mathrm{H}$ \\
\hline \multicolumn{6}{|l|}{ Spikelet fertility } \\
\hline BRRI9A/BR168R & 87.69 & $1.13^{* *}$ & $3.61 * *$ & $7.07 * *$ & $\mathrm{H} \times \mathrm{H}$ \\
\hline Gan46A/BR168R & 84.61 & $4.87^{* *}$ & $-3.22 * *$ & $7.07 * *$ & $\mathrm{~L} \times \mathrm{H}$ \\
\hline BRRI9A/Gui99R & 84.27 & $1.52 * *$ & $3.61 * *$ & $3.26 * *$ & $\mathrm{H} \times \mathrm{H}$ \\
\hline D.ShanA/BR168R & 83.50 & 0.08 & 0.46 & $7.07 * *$ & $\mathrm{~L} \times \mathrm{H}$ \\
\hline BRRI9A/BR6723-1-1-2R & 82.76 & $1.44 * *$ & $3.61 * *$ & $1.82 *$ & $\mathrm{H} \times \mathrm{H}$ \\
\hline \multicolumn{6}{|l|}{1000 grain weight } \\
\hline BRRI9A/M.H.63R & 27.90 & 0.02 & $1.72 * *$ & $2.25 * *$ & $\mathrm{H} \times \mathrm{H}$ \\
\hline BRRI9A/IR64R & 27.72 & $0.77 * *$ & $1.72 * *$ & $1.33 * *$ & $\mathrm{H} \times \mathrm{H}$ \\
\hline Gan46A/IR40750R & 27.64 & $1.15^{* *}$ & $1.50 * *$ & -0.07 & $\mathrm{H} \times \mathrm{L}$ \\
\hline BRRI9A/Gui99R & 27.30 & $1.17^{* *}$ & $1.72 * *$ & $0.50 *$ & $\mathrm{H} \times \mathrm{H}$ \\
\hline Gan46A/BR827R & 27.23 & $2.31^{* *}$ & $1.50 * *$ & $-0.48^{*}$ & $\mathrm{H} \times \mathrm{L}$ \\
\hline \multicolumn{6}{|l|}{ Grain yield/plant } \\
\hline BRRI9A/BR168R & 26.87 & $67.81^{* *}$ & $93.93 * *$ & $139.38 * *$ & $\mathrm{H} \times \mathrm{H}$ \\
\hline D.ShanA/BR168R & 24.23 & $18.84^{* *}$ & 5.53 & $139.38 * *$ & $\mathrm{~L} \times \mathrm{H}$ \\
\hline BRRI9A/BR827R & 24.20 & $58.97 * *$ & $93.93^{* *}$ & 9.17 & $\mathrm{H} \times \mathrm{L}$ \\
\hline II32A/BR168R & 23.90 & $-14.00 *$ & $20.80^{*}$ & $139.38 * *$ & $\mathrm{H} \times \mathrm{H}$ \\
\hline BRRI9A/IR40750R & 23.79 & $18.80^{* *}$ & $93.93 * *$ & $27.69 *$ & $\mathrm{H} \times \mathrm{H}$ \\
\hline
\end{tabular}

$\mathrm{H}=$ High gca effect; L= Low gca effect 
Crosses with desirable sca effects for various traits along with mean performance and gca effects of parents involved in the crosses are listed in the Table 4. The crosses BRRI9A $\times$ BR168R and D.ShanA $\times$ BR168R expressed significant sca effects as well as high per se performance for grain yield per plant and some other traits. However, II32A $\times$ BR168R and D.ShanA $\times$ BR6723-1-1-2R for days to 50\% flowering (earliness), D.ShanA $\times$ IR64R for plant height (dwarfness), Jin23A $\times$ BR168R and IR58025A $\times$ BR6723-1-1-2R for number of effective tillers, BRRI9A $\times$ BR168R and BRRI9A $\times$ Gui99R for panicle length, BRRI9A $\times$ BR168R and Gan46A $\times$ BR827R for panicle weight, BRRI9A $\times$ BR168R and BRRI9A $\times$ Gui99R for spikelet fertility, BRRI9A $\times$ M.H.63R and BRRI9A $\times$ IR64R for 1000 grain weight had high mean performance and highly significant mean values. These desirable cross combinations involved high $\times$ high type of general combiners. Kalitha and Upadhaya (2000), Shivani et al. (2009) and Salgotra et al. (2009) also reported about interaction between positive and positive alleles in crosses involving high $\times$ high combiners which can be fixed in subsequent generations if no repulsion phase linkages are involved.

The desirable performance of combinations like high $\times$ low may be ascribed to the interaction between dominant alleles from good combiners and recessive alleles from poor combiners (Dubey 1975). Such combinations were observed in the hybrids; II32A $\times$ IR44675R and D.ShanA $\times$ IR44675R for days to 50\% flowering (earliness), Jin23A $\times$ IR64R and IR58025A $\times$ M.H.77R for plant height (dwarfness), BRRI9A $\times$ BR168R and IR58025A $\times$ IR40750R for number of effective tillers, D.ShanA $\times$ BR168R for panicle length, Gan46A $\times$ IR40750R and II32A $\times$ M.H.63R for panicle weight, Gan46A $\times$ BR168R and D.ShanA $\times$ BR168R for spikelet fertility, Gan46A $\times$ BR827R and Gan46A $\times$ IR40750R for 1000 grain weight, D.ShanA x BR168R and BRRI9A $\times$ BR827R for grain yield per plant. Peng and Virmani (1990) also reported the possibility of interaction between positive alleles from good combiner and negative alleles from poor combiner in high $\times$ low cross combination and suggested for the exploitation of $F_{1}$ generation, as their high yielding potential would be unfixable in succeeding generation.

Involvement of both the poor combiners also produced superior specific combining hybrids as evidenced from the combinations: Gan46A $\times$ Gui99R for days to $50 \%$ flowering (earliness) and BRRI9A $\times$ BR168R and IR78362A $\times$ IR44675R for plant height (dwarfness). Involvement of both the combiners with low gca has been attributed to over dominance and epistasis interaction, which has been suggested by Amrithadevarathinam (1983), Singh et al. (2005) and Dalvi and Patel (2009). In majority of the crosses, high sca was mainly either due to high $\times$ low or low $\times$ low combining parents, which further substantiate the operation of non-additive gene action (additive $\times$ dominance and dominance $\times$ dominance epistatic interaction).

The crosses BRRI9A $\times$ BR168R and BRRI9A $\times$ BR827R were identified as most promising for yield based on sca effects. Hence these could be used for the exploitation of heterosis for yield and related characters. These best combiners could be utilized in hybrid development breeding program.

\section{References}

Amirjani MR 2011. Effect of salinity stress on growth, sugar content, pigments and enzyme activity of rice. Int. J. Bot. 7(1): 73-81.

Amrithadevarathinam A 1983. Combining ability and heterosis in dry and semi-dry paddy. Madras Agric. J. 70: 233-237.

Ashikari M, Sakakibara H, Lin S, Yamamoto T and Takashi T 2005. Cytokinin oxidase regulates rice grain production. Science 309: 741-745.

Bashar MK 2002. Genetic and Mopho-Physiological bases of heterosis in rice (Oryza sativa). Ph.D. thesis in Genetics and Plant Breeding. BSMRAU, Salna, Gazipur. 
Dalvi VV and Patel DV 2009. Combining ability anlysis for yield in hybrid rice. Oryza 46(2): 97-102

Dubey, RS. 1975. Combining ability for cigar filler tobacco. Indian J.Gen. Plant Breed. 75: 76-82.

Ikehashi H Zou JS Moon HP and Maruyana K1994. Wide compatibility genes and Indica-Japonica heterosis in rice for temperate countries. In: Hybrid Rice Technology: New Development and Future Prospects, Virmani SS (ed), pp. 1-6. Int. Rice Res. Inst., Manila, The Philippines.

Jennings PR 1964. Plant type as a rice breeding objective. Crop Sci. 4: 13-15.

Kalitha, U.C. and Upadhaya, LP. 2000. Line x Tester analysis of combining ability in rice under irrigated low land condition. Oryza 37: 15-19.

Kempthorne O1957. An Introduction to Genetic Statistics, John Wiley and Sons, Inc., London.

Khush GS. 2005. What it will take to feed five billion rice consumers by 2030. Plant Mol. Biol. 59: 1-6.

Honarnejad R, Abdollahi S, Mohammad-Salehi MS and Dorosti H 2000. Consideration of adaptability and stability of grain yield of progressive rice (Oryza sativa L.) lines. Res. Agric. Sci. 1: 1-9.

Peng JY and Virmani SS 1990. Combining ability for yield and yield related traits in relation to breeding in rice. Oryza 27: 1-10.

Richhari AK and Singh RS 1983. Heterosis in relation to per se performance and effects of general combining ability in rice. Progresses scientific meeting on genetics and improvement of heterotic systems. Coimbatore, India.

Rita B and Motiramani NK 2005. Study on gene action and combining ability in rice. Oryza 42: 153-155

Saidaiah PS, Kumar S and Ramesha MS2010. Combining Ability Studies for Development of New Hybrids in Rice over Environments. J. Agric. Sci. 2(2): 225-233.

Salgotra RK, Gupta BB and Praveen Singh 2009. Combining ability studies for yield and yield components in basmati rice. Oryza 46(1): 12-16.

Sarker U2001. Combining ability of CMS and restorer lines in rice (Oryza sativa L). MS Thesis. BMSRAU, Salna, Gazipur. Bangladesh. p. 96.

Satyanarayana PV, Reddy MSS, Kumar I and Madhuri J2000. Combining ability studies on yield and yield components in rice. Oryza 37: 22-25.

Shanthi P, Shanmugasundaram P and Nagarajan P 2003. Combining ability analysis in rice. Oryza. 40(1/2): 11-13.

Sharma PR Khoyumthem P Singh NB and Singh NK 2005. Combining ability studies for grain yield and its component characters in rice (Oryza sativa L.). Indian J. Genet. 65(4): 290- 292.

Shivani D, Viraktamath BC and Shobha Rani N 2009. Combining ability for yield and grain quality characters in indica/indica hybrids of rice. Oryza 46(2): 152-155.

Singh NK and Kumar A 2004. Combining ability analysis to identify suitable parents for heterotic rice hybrid breeding. IRRN 29(1): 21-22.

Singh RV Maurya DM, Dwivedi JL and Verma OP 2005. Combining ability studies on yield and its components using CMS lines in rice (Oryza sativa L.). Oryza 42: 306-309.

Srividya A, Vemireddy LR, Hariprasad AS, Jayaprada M and Sridhar S 2010. Identification and mapping of landrace derived QTL associated with yield and its components in rice under different nitrogen levels and environments. Int. J. Plant Breed. Genet. 4: 210-227.

Swamy MH, Gururaja Rao MR and Vidyachandra B 2003. Studies on combining ability in rice hybrids involving new CMS lines. Karnataka J. Agril. Sci. 16(2): 228-233.

Torres EA and Geraldi IO 2007. Partial diallel analysis of agronomic characters in rice (Oryza sativa L.). Genetics and Molecular Biol. 30(3) 605-613.

Venkatesan M, Anbuselvam Y, Elangaimannan R and Karthikeyan P2007. Combining ability for yield and physical characters in rice. Oryza 44(4) 296-299.

Yuan LP 1994. Increasing yield potential in rice by exploitation of heterosis. In: Hybrid Rice Technology: New Development and Future Prospects, Virmani, S.S. (ed), pp. 1-6. Int. Rice Res. Inst., Manila, The Philippines.

(Manuscript received on 25 March, 2013; revised on 14 July, 2013) 